$\begin{array}{llllllllllll}A & R & T & I & C & U & L & O\end{array}$

\title{
Las Nuevas Liturgias Patrióticas: Celebraciones en Santa Marta, CON OCASIÓN DE LA ELECCIÓN Y Posesión de TRes Presidentes NeOgRANAdinos
}

\author{
Por: Edgar Rey Sinning
}

\section{RESUMEN}

Celebrar, recordar, rendir homenaje, son prácticas culturales universales, asumidas por los individuos, los colectivos y los gobiernos, para convocar, publicitar, intensificar dinámicas de integración e identidad y, particularmente, para legitimar un orden propuesto.

Las celebraciones festivas de carácter colectivo, de origen y finalidad civil, con ocasión del triunfo electoral y posesión presidencial de tres mandatarios neogranadinos, que tuvieron lugar en Santa Marta, es el tema del presente artículo. En él se plantea que tales celebraciones se constituyeron en expresión de formas laicas y republicanas de conmemoración pública, que entraron a competir simbólicamente en las tradicionales celebraciones religiosas locales. Aquéllas asumen, ocupan, resignifican y recuperan prácticas, imágenes, signos, rituales y discursos de la tradicionalidad católica hispánica y las pone al servicio de las nuevas prácticas discursivas y políticas republicanas, en la Colombia de mediados del Siglo XIX.

\section{Preliminares}

/elebrar, recordar y homenajear son prácticas culturales universales del ser humano, de la familia, de la comunidad/sociedad y de los gobiernos en general, no importando qué forma de Estado sea. Recordar fechas importantes es para la persona (nacimiento), para la familia (matrimonio de los padres), para la comunidad/sociedad (patrono, fundación del pueblo o ciudad, creación como municipio o departamento) y para los gobiernos y autoridades (liberación, batallas, firma de pactos, creación de organismos) actos que convocan a todos. En tanto que los convocados son todos los asociados, compromete a todos sin distinción de clases, partidos, credos o razas. 
Cada una de esas fiestas está asociada a celebraciones que implican varios aspectos que se deben tener presente al momento de estudiarlas. Estos aspectos definen el tipo de fiesta. Hay fiestas alegres (Carnavales, patronales), de recogimiento (Semana Santa, Corpus Christi) y otras de conmemoración histórica (patrias y cívicas); son fiestas oficiales y con mucha fuerza política. Son fiestas "donde lo impecable, el esmero por lucir más serio y formal que los otros es el elemento central, se realizan para condecorar, para celebrar un aniversario de una batalla o la firma de un acta de independencia o algo parecido, son fiestas que se convocan para afirmar el carácter oficial de un Estado cualquiera que él sea". ${ }^{1}$ Mientras las primeras convocan a la igualdad transitoria, éstas convocan para ratificar la desigualdad social permanente entre clases y recordarles a los gobernados quiénes son los gobernantes que deben obedecer. Peter Burke señala que era tradicional en Europa que "el repertorio de rituales públicos también estaba presente en determinados eventos que no formaban parte del ciclo anual de fiestas. Ejecuciones públicas, la «entrada» solemne de personajes importante en la ciudad, la celebración de victorias (o coronaciones, o nacimientos de infantes reales)". ${ }^{2}$

Las fiestas alegres, de regocijo popular, reivindican la vida misma, no son un espectáculo para el goce de otros, por el contrario, son "una forma concreta de la vida misma". ${ }^{3}$ Estas fiestas involucran a toda la comunidad sin distingos de clase o credo, durante ellas no hay otra vida que esa, la vida festiva, de goce colectivo. Este goce, supone una vida diferente a la cotidiana, puesto que es la otra vida, la vida festiva. Estas fiestas no son decretadas ni autorizadas formalmente, hombres y mujeres las asumen como propias, que les pertenecen. Tanto así, que los festejos tienen un personaje festivo que asume la autoridad, como mandamás de la fiesta, él o ella reemplaza la autoridad civil en forma transitoria. Por el contrario, las fiestas patrióticas, cívicas y oficiales, tienden a ratificar el poder, son fiestas donde las autoridades siguen cumpliendo esa función. Las personas no tienen una real participación, sino que son simples asistentes a un espectáculo organizado para recordar próceres, héroes y; ratificar el Estado y la sociedad como tal. "Es un ritual diurno, claro, donde los espacios están bien marcados" ${ }^{4}$, que incluyen desfiles militares, despliegue de armamentos bélicos y otras expresiones del poder.

En Colombia durante todo el periodo colonial y luego en el republicano, las fiestas de carácter religioso son las que van a marcar la pauta en la naciente República de Colombia. Entre ellas se debe incluir por ejemplo, el carnaval y la fiesta de Corpus. Después de la Independencia se van a conmemorar los días en que se dieron batallas u otros hechos significativos para romper con la Corona Española. Sabemos de los festejos de Cartagena el 11 de noviembre de 1812 para celebrar el primer aniversario de la Independencia de la ciudad del yugo español. Festejos

${ }^{1}$ REY SINNING, Edgar. El Carnaval, la segunda vida del pueblo, Bogotá: Plaza \& JanesUniversidad Simón Bolívar, 2004, pág. 33.

2 BURKE, Peter. La cultura popular en la Europa Moderna, Madrid: Alianza 1991, pág. 281.

${ }^{3}$ BACHTIN, Michael. La cultura popular en el medioevo y en el $r$ e n a c i m i e n t o Barcelona: Barral 1974, pág. 13.

${ }^{4}$ DA MATTA, Roberto. Carnavales, balandros y héroes, México: Fondo de Cultura Económica, 2002, pág. 65. 
5 GONZÁLEZ PÉREZ, Marcos. El calendario festivo. En: Los Imaginarios y la cultura popular, Bogotá: Cerec, 1993, pág. 27.

6 GONZALEZ PÉREZ, Marcos. Bajo el Palio y el Laurel, Bogotá: Fondo de Publicaciones Universidad Distrital Francisco José de Caldas, 1995, pág. 78.

que llegan hasta nuestros días. En la historia encontramos las festividades "Del Triunfo" decretadas por la Asamblea de Cundinamarca, para el 19 de septiembre de 1819, para agasajar a Simón Bolívar y a todo el ejército patriota después del triunfo en la Batalla de Boyacá. En la misma acta se establece que "el día siete de agosto de todos los años se celebrará el glorioso aniversario de aquella jornada". ${ }^{5}$ Este festejo llega hasta nuestros días, como también el 20 de julio. Estas fiestas fueron adquiriendo "formas culturales", festejos populares que cada vez se acercaban a las fiestas religiosas, se fueron reemplazando hasta las imágenes religiosas por héroes, la corona de espinas del Jesús crucificado fue reemplazada por la corona de laurel, como símbolo de libertador, de héroe, "los elementos sonoros, los arcos triunfales, los ornatos, los colores, las banderas, las flores, las lágrimas, las estatuas, las alfombras y otros que figuran ya en el marco de la ritualidad religiosa, adquieren una significación específica en el nuevo contexto dentro del cual se presentan". ${ }^{6}$ Lo mismo sucede con el orden de la procesión, trasladándose los desfiles, la pólvora y los fuegos artificiales de los festejos religiosos y populares a los desfiles patrios y oficiales.

Las fiestas patrias continuarán siendo recordadas, año tras año. Desde luego entrarán en el nuevo calendario festivo de la naciente Nación. Son ordenadas a través de normas que se establecen en los órganos del poder, con sede en Bogotá y replicadas en todo el territorio. Son días festivos

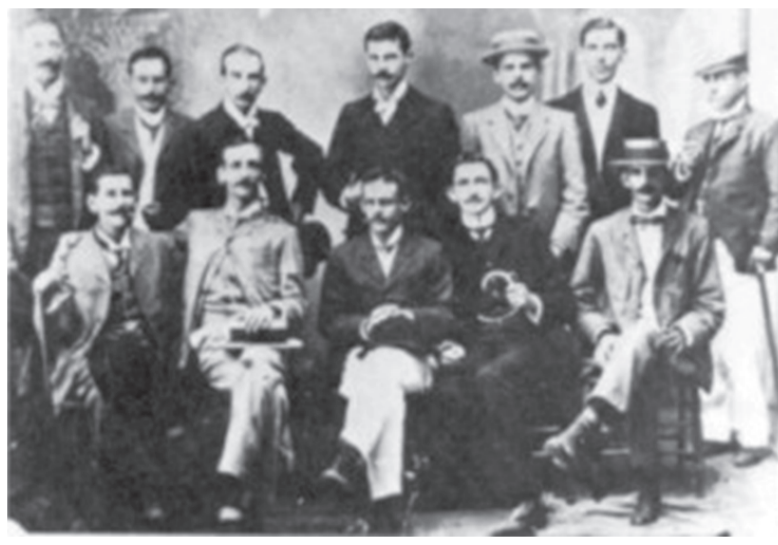

Foto: ANONIMO. Grupo de Caballeros, Santa Marta, ca. 1898* consagrados a la recordación del triunfo y al desconocimiento de la autoridad del Rey y la Corona Española. Estas celebraciones se trasladan, igualmente, a los triunfos de los partidos políticos y a las posesiones de los Presidentes. En muchos casos, quienes los organizan son los triunfadores y convocan a toda la población a sumarse y asistir, inclusive, a participar de los festejos en el marco de la exaltación del triunfador al solio de Bolívar. Estas iniciativas partidistas cuentan con el apoyo de las autoridades civiles, militares y eclesiásticas, como también de la prensa local partidista. Son celebraciones coyunturales, con mucho valor simbólico para la conformación de la Nación y de la democracia.

\section{Santa Marta Patriótica y Rumbera Durante la Posesión de Tres Presidentes Neogranadinos}

* Tomado de: http://www.lablaa.org/ blaavirtual/historia/stm/ stm23.htm\#2531
En la medida en que se consolida la República y se deja atrás en forma definitiva el fantasma del Rey y sus autoridades virreinales en el territorio nacional, avanza 
la organización de los partidos. Igualmente, aparecen caudillos locales y regionales, conflictos político-militares que evolucionan a guerras civiles, que son constantes en el siglo XIX. La forma de organizar el Estado, bien sea a través de gobiernos federales o centralistas será durante todo el siglo, el centro de la discusión ideológica partidista. De todas las formas se intentó hasta que en 1886 se consolidó el centralismo con la Constitución Política de ese año.

El triunfo de los caudillos en confrontaciones políticas o militares, era motivo más que suficiente para organizar fiestas espontáneas en su lugar de nacimiento o residencia y sobretodo por parte de sus seguidores. Esta es una vieja tradición europea puesto que "las victorias significaban banquetes, fuegos artificiales y hogueras". ${ }^{7}$ Santa Marta, como todas las ciudades nuestras del siglo XIX, vibró con la acción política de sus dirigentes y con la de algunos líderes nacionales que tenían sus partidarios en la vecindad. Como toda ciudad portuaria, era una puerta de ingreso a la nación, por lo que gozó de los avances científicos y sobretodo tecnológicos de la modernidad; contó desde muy temprano con periódicos editados en los varios talleres tipográficos existentes en la ciudad. Disponer de varios semanarios en los primeros años republicanos, les permitió a muchos samarios expresar públicamente sus pensamientos políticos y literarios, por lo que la ciudad y toda la provincia se mantenía en la discusión ideológicapolítica de los nacientes partidos. Eso explica la pasión con que se crean periódicos, bien conservadores bien liberales, pero también la forma como se expresan los columnistas y los dueños de estos medios. El compromiso con el partido, la defensa de la democracia, de la libertad, la invocación permanente a la unión, la fraternidad, la concordia y sobretodo la hermandad, son temas diarios y lemas de estos periódicos.

Así como se vive la política intensamente, así es la fiesta. Espíritus festivos, manifiestos en el goce colectivo de los días de carnavales, en las fiestas religiosas y las que nos recuerdan la Independencia del yugo español, a todas ellas se les suman otros motivos para organizar fiestas públicas con carácter popular. Motivos suficientes tenían los samarios para festejar cuando se elegían los presidentes y el día de la posesión se convertía en un verdadero acontecimiento patriótico y de regocijos públicos. Para la época los presidentes se posesionaban el primero de abril, en actos significativos para los samarios. Una posesión que nos permite ilustrar el tema y acercarnos a ese espíritu festivo de los samarios fue la del General Tomás Cipriano de Mosquera (1845-1849).

Días antes de la elección, los samarios organizaron una fiesta de tres días y en su víspera con el lema "fuera quien fuese" todos se prepararon para ella. Los samarios

7 BURKE, Peter, Op. Cit. pág. 281. 
${ }^{8}$ LA FRIOLERA, No. 3, Santa Marta, 1845. pág. 3.

${ }^{9}$ Ibid.

${ }^{10}$ Ibid. de ambos partidos estaban convencidos que no importaba quien ganara. Lo importante era que el escogido fuera de la terna que resultó del proceso de selección surtido en las provincias, como en efecto sucedió. La fiesta pública tuvo la acogida de por lo menos dos de los semanarios que se publicaban para la época en la ciudad: "La Friolera" y "El Semanario de Santamarta". El primero nos informa el 22 de marzo de 1845 que "los siguientes programas que se han publicado en el No.15 del Semanario de esta ciudad, se reimprimen para que se haga más extensiva su circulación". ${ }^{8}$ Infortunadamente el periódico señalado falta en la colección, existente en la Hemeroteca Nacional de Colombia.

Sin duda que la reimpresión del programa acordado para los festejos en "La Friolera" va a ser muy significativo porque los suscriptores de estos medios casi nunca eran los mismos, de tal manera que eso garantizaba que llegaría la información a muchos samarios y otras ciudades donde estos periódicos tenían suscriptores. El programa acordado fue el siguiente: "Los ciudadanos vecinos de la ciudad de Santa Marta, deseosos de saludar el día $1^{\circ}$ de abril al nuevo Presidente de la República, con vivas demostraciones de júbilo por su advenimiento a la silla presidencial, han determinado solemnizar este día, y los dos subsecuentes con las siguientes fiestas públicas. Víspera del $1^{\circ}$ de abril. Iluminación general, para cuyo objeto se invita al Sr. Jefe Político, debiendo en esta noche recorrer la ciudad la banda de música. Día $1^{\text {o }}$ Cuadrillas de a caballo por la tarde en la plaza de la Constitución; baile por la noche en el local del Concejo municipal, que lo darán el Sr. Gobernador y el Sr. Comandante general unidos con los señores empleados civiles y de hacienda, oficiales de la guarnición, y empleados militares". ${ }^{9}$ La organización de los festejos tiene una clara demarcación social, si se tiene en cuenta que el espectáculo de las cuadrillas es en el día, lo que permite la asistencia de todos sin distinción. La situación cambia para los actos de la noche puesto que el baile es en un local cerrado, ofrecido por funcionarios y miembros de las fuerzas militares de la época. La música será distinta, igualmente, a la que amenizará los bailes populares en algunas viviendas y sitios públicos de la ciudad.

El “día $2^{\circ}$ Despejo por la tarde que lo ejecutará el Batallón No. 9. Por la noche baile en el mismo local del Concejo municipal, que lo darán los Sres. Comerciantes de esta ciudad. Día $3^{\circ}$ Toros por la tarde, siendo de cargo de los artesanos de esta ciudad preparar los toros y cercar la plaza. En todos los mencionados días habrá iluminación general, y además se permitirá toda clase de regocijos públicos durante las fiestas". ${ }^{10}$ El programa concluye que "de este modo se promete el pueblo de Santa Marta hacer su salutación al ciudadano que por el voto popular sea colocado bajo el dosel de la presidencia, probando así su acatamiento y 
beneplácito por su elección, sea quien fuere el hombre en quien recaiga". ${ }^{11}$ De tal manera que los samarios están apostándole a los procesos democráticos que se consolidan en la naciente República. Lo importante es evitar la confrontación militar como consecuencia de las desavenencias caudillistas. La última frase del programa "sea quien fuere..." es una forma de expresar la complacencia por los tres candidatos, no importando el ganador.

Ahora bien, el programa establece diferencias bien marcadas cuando señala que el "despejo", es decir, lo primero, es el desfile militar que dará el Batallón, lo que implica una demarcación social porque el desfile define una organización milimétrica, unos soldados desfilando ordenadamente, uniformados y haciendo alardes del poder que les permite las armas de la nación. El pueblo, los sectores populares serán asistentes más no participantes del desfile. Otros dos detalles que se aprecian en la programación son: ¿quiénes tienen el derecho de ofrecer un baile en la Casa Municipal? : Los comerciantes, es decir, el poder económico de la ciudad. Por el contrario, la tarde de toros, corre por cuenta de los artesanos que en la estratificación social están por debajo.

En ambos semanarios samarios hubo comentarios tanto de opositores como de afectos al General Tomás Cipriano de Mosquera. Más adelante mostraremos algunas reacciones al tema ideológico, ahora demos una mirada a los festejos siguiendo esta vez el periódico "El Semanario de Santamarta", del 13 de abril, que brinda casi todas sus páginas a informar de los festejos día por día. La noticia que aparece en la primera página con el titular de "NO OFICIAL...Fiestas Públicas" se inicia con una reflexión interesante sobre lo acontecido en la ciudad, el entusiasmo y la concordia que reinaron entre todos los samarios "como hijos de una misma patria".

Las fiestas fueron todo un éxito, por lo que se ha cumplido "el objeto a que se dirigieron estas públicas demostraciones; y que la diligente cooperación de cuantos tuvieron parte en ellas es un plausible motivo de regocijo para los que aprecian la concordia y la fraternidad entre hijos de una misma patria entre granadinos que solo aspiran a la dicha futura de la República" ${ }^{12}$ Reconocen los editores del periódico que desde el momento mismo de conocerse la terna y la convocatoria los festejos patrios tuvieron gran receptividad por parte de todos los samarios sin distingos de partido político. La nota nos informa que se cumplió lo programado para las vísperas del $1^{\circ}$ de abril y que la ciudad verdaderamente estaba iluminada, por todas partes se respiraba regocijo y alegría, la banda de músicos del Batallón, recorrió las calles acompañada de una gran multitud de samarios, que bailaban y gozaban al ritmo de los aires musicales del momento 25, 1845. pág. 1.
} 
${ }^{13}$ EL SEMANARIO DE SANTAMARTA, NO. 25, Santa Marta, 1845. pág. 1-2.

${ }^{14}$ Op. Cit. pág. 2.

${ }^{15}$ Ibid. y agitaban consignas políticas de hurras a los congresistas y al presidente saliente, el General Pedro Alcántara Herrán.

El primer día los samarios madrugaron a festejar el advenimiento de un nuevo presidente. El cronista dice en su informe que "al dejarse ver el sol en la mañana resuena este día una salva de artillería anuncio que había llegado la fecha que la Constitución tiene prefijada para la relevación del primer magistrado de la República (...) En seguida tuvo lugar una misa solemne con Te Deum en la Santa Iglesia Catedral, a la que asistió un número considerable de personas de ambos sexos; durante esta religiosa ceremonia; en que se elevaban preces al Ser Supremo por la felicidad futura de la República, y por el acierto administrativo del nuevo magistrado de ella". ${ }^{13}$ Así mismo señala que el obispo en su homilía recordó lo triste del pasado, los males que causaron a la sociedad y que era hora "de que se extinguieran para siempre hasta las ideas de subvertir por vías de hecho el orden público; que el ilustrado jefe que hoy empuñaba las riendas del gobierno, con su política, completaría la grande obra de la reconciliación general y la total fusión de los partidos que desgraciadamente desunieron a los granadinos, llamando a todos los hijos de la madre común en torno al pabellón nacional". ${ }^{14}$ El ideario político de los samarios era justamente lograr con estas fiestas la reconciliación local y nacional.

La tarde samaria estuvo llena de festejos populares y de un desfile de una cuadrilla de treinta y dos jinetes vestidos para la ocasión. Los samarios de todas las clases sociales y partidos políticos fueron convocados a la Plaza de la Constitución que estuvo muy concurrida "para presenciar (...) las diversas y variadas figuras que ejecutó una cuadrilla de treinta y dos jinetes; vestidos a su costa y con toda la elegancia que pueden proporcionar los posibles del país: constaba esta cuadrilla de cuatro bandas con trajes y caballos enteramente distintos los unos a los de la otra; ocho fogosos rucios los cabalgaban otros tantos individuos vestidos a la morisca; igual número de caballos negros llevaban ocho hombres en el traje de caballeros españoles; en ocho caballos castaños se dejaban ver ocho individuos vestidos a la romana; y en fin, ocho caballos amarillos soportaban el peso de ocho húsares a la inglesa". ${ }^{15}$ Acto seguido los jinetes mostraron una valla blanca con letras grandes que decía: "El pueblo samario felicita a S. E. el Presidente de la República General Tomás Cipriano de Mosquera". Luego se dieron los juegos entre los componentes de la cuadrilla y después de dos horas de diversión al aire libre, los asistentes se retiraron a sus casas a descansar para regresar a la juerga preparada para las 9 de la noche en la Sala del Concejo Municipal. Otros se quedarán en sus viviendas o en otros lugares acordes con su posición social. 
La fiesta se inició con un suntuoso baile y luego vino un ambigú; todo el disfrute de la noche corrió por cuenta de "los empleados civiles, militares y de hacienda, que gozan de sueldo por la nación" ${ }^{16}$ El cronista nos informa que todo era muy elegante y de buen gusto, la plaza estaba iluminada, llena de banderas con los colores nacionales y mensajes alusivos al Libertador Simón Bolívar. La aristocracia samaria, que disfrutaba del privilegio de ocupar cargos en la administración, mostró su poderío y su nivel jerárquico en la escala social de la ciudad. De todas maneras, ser funcionario de la Provincia de Santa Marta para la época era un privilegio que daba prestigio.

El segundo día de los festejos, fue como el anterior, lleno de alegría y regocijo general. En la tarde la tropa hizo el deleite de todos los asistentes a la Plaza de la Constitución. Los actos comenzaron a las cuatro de las tarde y concluyeron ${ }^{17}$ Ibid. entrada la noche, cuando la banda de música del Batallón inició su recorrido por las calles y callejones de la urbe samaria. Hubo licor y comida en abundancia, luego se dio el baile organizado por los comerciantes de la ciudad mientras todos esperaban la llegada del tercer día de festejos. Ese día llegó, en las horas de la mañana todos se entregaban a los preparativos para la jornada de la tarde. Fue responsabilidad de los artesanos organizar la tarde de toros que es un "entretenimiento que entre los españoles y sus descendientes es inmemorial, y se tiene como el complemento de toda fiesta". ${ }^{17}$ En la noche la fiesta continúo con el baile programado, el decorado del salón con elementos alusivos a exaltar el patriotismo de los samarios, banderas, retratos de los héroes nacionales y locales, mensajes vitoreando a los presidentes saliente y entrante.

Se informa que hubo muchos brindis por la Nación y la unión de todos alrededor del Presidente y el fortalecimiento de la democracia, el baile fue hasta

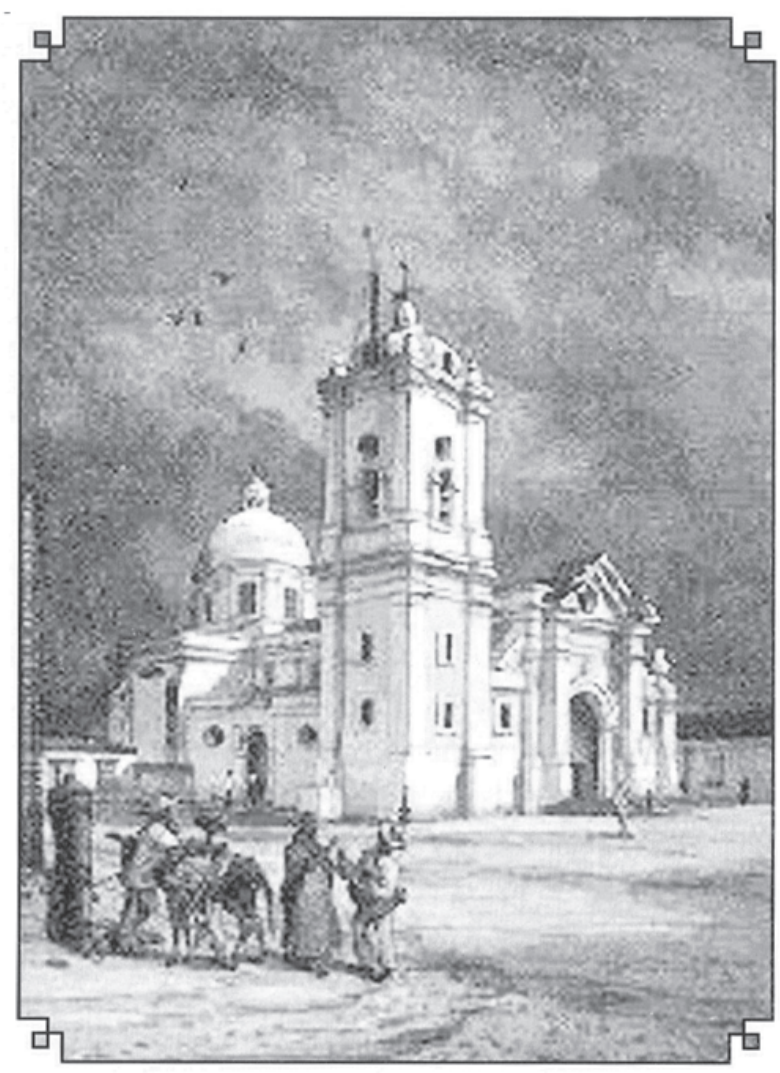

Catedral de Santa Marta, Edward Mark, 1844* muy tarde y que la ciudad estaba totalmente iluminada: "pasadas las doce de la noche, y después de haber transcurrido más de tres horas en un completo gozo, por la cordial unión que se respiraba, y por la modesta compostura que se notaba en todos los concurrentes, se procedió al ambigú preparado en una casa contigua a la municipal, había allí una suntuosa y espléndida mesa cubierta de diversidad de manjares, y de exquisitos licores, vestida al propio tiempo con innumerables

* Acuarela sobre papel, $25,3 \times 17,3 \mathrm{cms}$ Colección de Arte del Banco de la República. Tomado de: Ospino Valiente, Álvaro, Santa Marta Vista por Viajeros. Referentes de Ciudad, Bastianos Editores, Colombia, 2005. 
banderas..." ${ }^{18}$ Como puede verse, los samarios no solo homenajearon al nuevo mandatario sino que aprovecharon el tiempo y los espacios para el goce colectivo.

En estos festejos encontramos tres ejes centrales para destacar. El primero es el ritual del Te Deum, es decir, fiesta religiosa, de igualamiento aparente, de neutralización en términos de Da Matta. Porque si bien es cierto que todos están en la "casa de Dios", unos tienen sus lugares reservados y respetados por todos. Esos son los sitios para que se sienten las autoridades civiles, los comandantes de las fuerzas militares, los diputados, los comerciantes, los funcionarios públicos, los aristócratas y las nacientes elites y uno que otro artesano. Más atrás estarán los otros, los sectores populares. El segundo ritual es el del refuerzo, siguiendo al antropólogo brasilero. Es decir, los actos patrióticos que expresan y reafirman las jerarquías sociales en la sociedad samaria. El tercer ritual es el de la inversión, los actos festivos carnavaleros, que son el deleite de todos los sectores, cada uno disfrutando de la permisibilidad de la fiesta en su lugar, en su "charca".

Cuatro años más tarde la ciudad y el país en general, se preparaban para una nueva elección presidencial y por supuesto los samarios se disponían también para el goce colectivo que autorizaban las autoridades y los partidos políticos con motivo de la elección y posesión del reemplazo del General Mosquera. Lo interesante es ver cómo el proceso de fortalecimiento de la democracia avanza. Para estas elecciones aparecen tres candidatos, dos conservadores Rufino Cuervo y José Joaquín Gori y el partido liberal unido alrededor del General José Hilario López. El 7 de marzo de 1849 después de tres votaciones salió elegido como nuevo Presidente el General José Hilario López. La noticia apareció en el semanario "El Churiador" del domingo 18 de marzo. Afecto al General López, el periódico saluda y felicita a los congresistas por tal decisión y afirma "nosotros celebramos la elección del General López más bien como granadino, que como sus partidarios políticos". ${ }^{19}$ Apenas se enteraron los samarios del hecho político partidista organizaron un baile para el 22 de marzo de ese año e invitaron a los seguidores de Cuervo; "en la fachada de los billetes de convite, se leían estas tres palabras, Libertad, Igualdad, Fraternidad, y ellas reinaron también durante el baile". ${ }^{20}$ A pesar de la invitación y de que asistieron algunos cuervistas, en la ciudad corrió la noticia, a manera de chisme, de que alguno de los organizadores del baile

${ }^{18}$ Ibid.

${ }^{19}$ EL CHURIADOR, No. 5, Santa Marta, 1849 pág. 1.

${ }^{20}$ EL CHURIADOR, No 6, Santa Marta, 1849. pág. 4. había manifestado la intención de no invitar a ninguno de ellos. En el mismo periódico se cuestiona tal comentario, se desmiente y afirma que nunca se pensó en ello y que además sería una falta de educación.

La posesión de José Hilario López se dio el día establecido por la Constitución, pero las fiestas no. Estas se dieron días después, como nos lo informa el periódico 
"El Churiador", al registrar la complacencia por los festejos de los días 8, 9 y 10 de abril, al considerarla como una verdadera fiesta cívica, patriótica, con participación de todas las clases sociales. La posible razón del cambio de fecha obedeció a la coincidencia de las fechas tradicionales con la celebración de la Semana Santa, ya que el $1^{\circ}$ de abril fue domingo de Ramos. Otro periódico de la época comenta que "aunque no han podido celebrarse los regocijos que se tienen prevenidos hasta el 8, por caer en la Semana Santa los primeros días del mes, se saludó por el pueblo samario la aurora de ese primer día de la administración López con verdadero entusiasmo. A las doces de la noche se enarboló el Árbol de la Libertad en la plaza de la Constitución al son de la música, y al estruendo de cohetes y vivas de una muy numerosa concurrencia; un gorro de raso encarnado y debajo una corona de laurel, eran los emblemas. Luego la concurrencia recorrió las calles con la música, dando alegres vítores, y agregándose sin cesar individuos que salían de sus moradas a participar del contento público. Al ser de día se hizo una salva de veintiún cañonazos, seguida de dos descargas de fusilería por el batallón $6^{\circ}$. En medio del alborozo que se veía en todos los rostros, fueron invitados algunos sujetos a dirigir la palabra al pueblo y en efecto desde la galería de la Casa Municipal los Sres. Dres. Antonio Del Real, Antonio González Carazo y Juan Manuel Pérez hicieron elogios a la libertad y al nuevo presidente" ${ }^{21} \mathrm{El}$ cronista insiste en el carácter patriótico de los discursos, destaca igualmente el comportamiento de los samarios, finalizando la nota diciendo: "así celebra un pueblo culto y libre sus fiestas nacionales". ${ }^{22}$ De tal manera, que a pesar de los días santos los samarios no sólo festejaron el $1^{\circ}$ de abril, sino que amanecieron con la música. Un detalle importante fue la colocación de una corona de laurel, el árbol de la libertad en la Plaza de la Constitución. Tradición de colocarle a los triunfadores una corona de laurel, ya lo vimos en los festejos del 19 de septiembre de 1819 en Bogotá. Esta práctica es una herencia, igualmente, europea; recuérdese que a Napoleón Bonaparte le fue colocada una, al ser coronado en Notre Dame.

Aunque no se publicó el programa en el semanario "El Churiador", sí apareció en la ciudad, como nos lo informa el mismo periódico, cuando dice en la edición del 15 de abril "acordado por varios ciudadanos el orden como debían celebrarse las fiestas populares, se señalaron los días 8, 9 y 10 del presente mes, y se publicó el programa correspondiente, por el cual se permitían en aquellos días con autorización de la policía toda clase de diversiones lícitas". ${ }^{23}$ El programa contemplaba actividades festivas en las vísperas, tales como iluminación total de la ciudad, fuegos artificiales y engalanamiento de la galería de la Casa Municipal, pero no fue posible gozar del espectáculo que se había acordado, pues las fuertes brisas que soplaban en la ciudad lo impidieron. Los juegos artificiales fueron trasladados para el día 9 en la noche cuando éstas amainaron.

\footnotetext{
${ }^{21}$ GACETA MERCANTIL, No. 78, Santa Marta, 1849

${ }^{22}$ Ibid.

${ }^{23}$ EL CHURIADOR, No. 9, Santa Marta, 1849. pág. 3.
}

Palobra No. 7 Agosto/2006 
${ }^{24}$ EL CHURIADOR, No.9, Santa Marta, 1849, pág. 3-4.

${ }^{25} \mathrm{Ibid}$.

${ }^{26}$ BURKER, Peter. Op. Cit. pág. 281.

${ }^{27}$ EL CHURIADOR, No.9, Santa Marta, 1849, pág. 3-4.
Los festejos públicos arrancaron el día 8 con una comida que contó con la asistencia de las autoridades locales y provinciales. Destaca la prensa que, a pesar de haberse concentrado en el día entre 400 y 500 personas, reinó la armonía y la fraternidad. En la noche los samarios se prepararon para gozar a los acordes de los ritmos alegres y de las marchas, ya que "la banda de música paseó largo tiempo por las calles de la ciudad, alumbradas por las luces de las ventanas y balcones". ${ }^{24}$ Con poca asistencia de personalidades se ofició misa y Te Deum en la catedral el día 9 en las horas de la mañana y "a las 5 de la tarde los grupos de gente que ocupaban la plaza de la Constitución, eran señales ciertas de una diversión nueva para nosotros, los balcones y ventanas que quedan en la plaza estaban llenos de señoras, y como a las 6 la fuente pública derramaba vino en lugar de agua, todo el pueblo ocurrió a tomar parte en aquella fiesta verdaderamente popular". ${ }^{25}$ Comenta el periódico en mención que ese espectáculo duró como 45 minutos, el pueblo se distrajo y ciudadanos liberales muy ricos de Santa Marta regaban monedas de plata, cuando se exclamaba: "Viva la Libertad" y otras consignas por el estilo. Peter Burke, encontró vestigios de estas formas de festejos en la Europa moderna cuando afirma que "las entradas reales comportaban la erección de arcos triunfales, mítines, batallas simuladas, fuentes por las que manaba vino y monedas lanzadas a la multitud". ${ }^{26}$ Nada de extraño que los samarios acaudalados hubiesen conocido esta tradición europea, a través de la lectura o por apreciación personal, puesto que los viajes al viejo continente eran muy comunes entre ellos.

Ese mismo día "a las siete de la noche estaba engalanada [la Plaza de la Constitución] con ricos cortinajes, y se veía perfectamente iluminada la galería de la casa municipal, el espacio central le llenaba con un suntuoso y brillante dosel de terciopelo carmesí ricamente bordado de oro, bajo el cual se veía el retrato del nuevo Presidente de la República". ${ }^{27}$ Esa noche hubo fuegos artificiales y "diversos caprichos pirotécnicos", una especie de castillo moderno y al final, bailes populares, tambores, gaitas y licor.

Estas celebraciones patrióticas liberales concluyeron el 10 de abril y en la noche se dio un baile en el colegio Seminario de la ciudad, considerado por el semanario local como, "brillante, suntuoso y magnifico baile (...) es el primero que hemos visto de mucho tiempo a esta parte. El lujo y elegancia fueron las ideas dominantes de las personas encargadas de preparar esta función (...) El salón estaba asiáticamente adornado, la concurrencia fue extraordinaria y las graciosas samarias estaban adornadas con primor y elegancia, reuniendo a sus gracias y bellezas, los adornos más exquisitos del arte (...) se sirvió ambigú con finura y delicadeza, todo estaba en abundancia y la civilicidad y cortesía se hizo sentir 
en las personas. Todos los rostros manifestaban contento, entusiasmo y satisfacción". ${ }^{28}$ El salón de los agasajos estaba adornado con varias banderas de seda importada y con letras de oro, con consignas políticas se destacaba una que se leía: "Viva BOLIVAR el grande, cuya espada libertó cinco naciones". Como puede deducirse los liberales desde el gobierno y con el poder económico de la ciudad, hicieron una gran fiesta que no dudamos en calificar de carnavalera. Si bien es cierto que tenía el tinte liberal, hubo asistencia masiva de samarios sin distingos políticos, raciales, religiosos y sociales.

El triunfo del General José María Obando, en 1853, liberal como los dos anteriores, fue inobjetable. Sus seguidores en Santa Marta le escriben y le auguran éxitos en su gobierno. El dirigente liberal local, comerciante y con mucho poder Don Manuel Abello, obsequió al Cabildo de la ciudad un retrato del recién electo presidente . El hecho ocurrió en la sesión del 7 de marzo de 1853, día simbólico para los liberales, por lo acaecido en 1849. Se acordó colocarlo con todos los honores el día $1^{\circ}$ de abril, cuando se debía posesionar el Presidente Obando.

Los actos estuvieron enmarcados durante los días tradicionales (1, 2 y 3 de abril) con sus respectivas vísperas. Si bien es cierto, que no apareció publicado los días anteriores, sí el día 7 de abril, cuando en otro lugar del periódico "El Iris" se narraban los eventos llevados a cabo. El programa fue organizado y divulgado en la ciudad el 26 de marzo. En él se muestra toda la solemnidad de la aristocracia samaria de estirpe liberal. El programa se elaboró de la siguiente forma: "1º De ABRIL Una salva de 21 cañonazos saludará la aurora de este gran día. La banda de música recorrerá en seguida las calles de la ciudad: habrá cohetes y repique de campanas. A las 9 se oficiará en la Catedral una misa solemne con Tedeum, a que asistirá medio batallón de Guardia Nacional, haciendo descargas de costumbre. A las 12 se repetirá la salva; y después de ella, la música anunciará que va a recibirse por una comisión del Cabildo, el retrato del Ciudadano General JOSÉ MARÍA OBANDO, que le ha obsequiado el Sr. Manuel Abello. A las 5 de la tarde tendrá lugar la recepción indicada, en la casa particular del Sr. Abello, marchando con la Comisión del Cabildo el medio batallón de Guardia Nacional, que debe hacer los honores al Ciudadano Presidente de la República. El Cabildo estará reunido en la Sala Municipal esperando a la Comisión con el retrato; y procederá luego a colocarlo en la galería alta, lujosamente decorada al efecto. La tribuna colocada en la Plaza de la Constitución, anunciará los discursos que han de pronunciarse por los ciudadanos. Por la noche, iluminación general; y a las 8 tendrá lugar un suntuoso baile en el Colegio. $2^{\circ}$ De ABRIL En la mañana, disfraces y regocijos públicos; a la tarde, toros en la Plaza de la Constitución con música en la galería municipal. Por la noche, iluminación general. $3^{\circ}$ De

${ }^{28}$ EL CHURIADOR, No. 9, Santa Marta, 1849, pág. 5. 
${ }^{29}$ EL IRIS. No. 14 , Santa Marta, 1853. pág. 2.

${ }^{30}$ Ibid.

${ }^{31}$ Ibid.

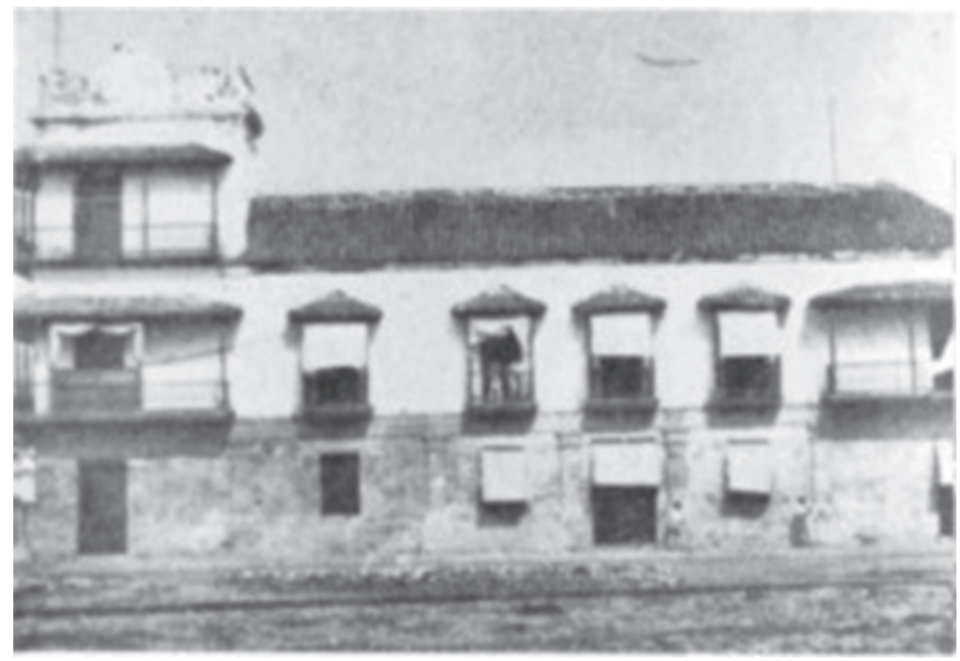

Foto: ANONIMO Casa de la Aduana, Santa Marta, $1890^{*}$

ABRIL En la mañana, disfraces y regocijos públicos, en la tarde se servirá una comida cívica a la Guardia Nacional en la galería de la nueva aduana. Por la noche, iluminación genera" ${ }^{29}$

Ese fue el programa que se dio a conocer a los vecinos de la ciudad, sin embargo en las vísperas se dieron unos actos de interés histórico-político que ilustran la forma de vivir y sentir la política en la ciudad en el siglo XIX. Igualmente es importante apreciar el significado de iniciar una procesión no religiosa, sino política, siguiendo un retrato, en este caso del Presidente electo. Los hechos que conocemos nos informan que "la víspera de ese gran día se reunieron muchos patriotas en casa del Sr. Antonio Locarno, (a la postre propietario de la imprenta donde se editaban varios periódicos entre ellos "El Iris") a las 10 de la noche, (...) y cuando ya el pueblo se encontraba agolpado a la puerta, se le presentó el retrato del nuevo Presidente, designando el Sr. Locarno a los Sres. Joaquín Viana y Dr. Cayetano Lombana para presentarlo. Al salir la música rompió una marcha, y el pueblo prorrumpió en aclamaciones al ilustre granadino que ha merecido su confianza para gobernarlo (...) formaron ala los concurrentes y salieron a recorrer las calles con el retrato, conducido primero por los Sres. Lombana y Viana, y sucesivamente por los Sres. Coronel Manuel Martínez, Miguel Zúñiga y otros ciudadanos. La bandera nacional flameaba sobre el retrato del ilustre Presidente. Después de recorrer las calles, entraron en la casa del Dr. Lombana, quien (...) obsequió a los concurrentes; teniendo lugar algunos brindis pronunciados" 30 por los que conducían el retrato.

Al cabo de un largo recorrido por las calles de Santa Marta, la procesión llegó a la casa del donante del retrato, don Manuel Abello, donde por supuesto los caminantes duraron bastante tiempo e invitaron al propietario de la casa a tomar la palabra, lo hizo "pronunciando un brindis en que, después de felicitarse y felicitar al pueblo por el comportamiento de sus deseos, hizo una ligera relación de las importantes reformas que se llevarán a cima durante el período de la Administración de Obando, el cual no tiene otra ambición que satisfacer las esperanzas de los pueblos". ${ }^{31}$ Al dirigente liberal le

* Tomado de: http://www.lablaa.org/ blaavirtual/historia/stm/ indice.htm contestaron copartidarios, con brindis de esperanza y júbilo que experimentaban los samarios. El señor Abello se sumó a la procesión política y luego llegaron a 
las viviendas de otros liberales, como la de los señores José María Guerrero y Tomás R. Abello. En ambas hubo brindis y los seguidores consumieron algunos alimentos y mucho licor. La procesión terminó a la una de la mañana cuando todos se fueron a sus viviendas a descansar y a prepararse para los tres días de fiesta que se avecinaban. Coincidimos con el historiador Marcos González cuando afirma que "se pasa de la procesión al desfile, del culto religioso a la ritualidad patriótica con una semantización cívica de los elementos antes utilizados por la simbólica religiosa". ${ }^{32}$

En la mañana de ese $1^{\circ}$ de abril, se cumplió todo lo programado antes de la entrega oficial del retrato al cabildo, es decir, 21 cañonazos, misa, Te Deum. El señor Abello, haciendo uso de su poder económico, social y político, esperó en su casa la Comisión enviada por el Cabildo, que estuvo integrada por los Sres. Manuel S. Avendaño y Manuel Conde. El primero de ellos que presidía la Comisión pronunció un discurso que respondió el dirigente liberal Abello. Acto seguido, entraron a un carro preparado para la ocasión y el "batallón de Guardia Nacional (...) que se hallaba formado en toda la extensión de la calle, presentó las armas. Emprendida la marcha, la Guardia Nacional siguió custodiando el carro hasta la Casa Municipal". ${ }^{33}$ Cuando llegaron a la Plaza de la Constitución, la muchedumbre que esperaba ansiosa la comitiva y el retrato, inició un coro de Vivas a Obando. El desfile demarca los espacios y reafirma la jerarquización de la sociedad samaria. El retrato no solo era el emblema del poder presidencial, sino que, quienes lo portaban y quien lo donó simbolizaban el poder en la ciudad. Nuevamente se aprecian las diferencias sociales, cuando se da cuenta que los sectores populares copan el lugar histórico de los samarios, la Plaza de la Constitución, como simples asistentes, espectadores de un ritual que refuerza la autoridad y el orden en la ciudad.

La Sala municipal estaba decorada para la ocasión, muy elegante, donde se expresaba el poder económico de la naciente burguesía comercial samaria. El Cabildo en sesión extraordinaria, recibió el retrato de manos de su donante, quien no perdió la oportunidad para pronunciar otro discurso, que a su vez fue respondido por el señor Francisco Dávila que presidía la reunión y actuaba como Vicepresidente. "El retrato fue colocado en la galería bajo un magnifico dosel; y en seguida tomó la palabra el joven Luis Capella Toledo desde la misma galería, y habló al pueblo en un discurso poético, que mereció muchos aplausos". ${ }^{34}$ Después hubo otro discurso y la Guardia Nacional concluyó el acto con varias descargas y fuego graneado que duró hasta entrada la noche, cuando los samarios volvieron a sus viviendas a tomar un descanso. Unos volvieron a sus "conejeras" a seguir disfrutando de la permisividad decretada y otros a vestirse

${ }^{32}$ GONZÁLEZ PÉREZ, Marcos. Bajo el Palio y el Laurel, Bogotá: Universidad Distrital Francisco José de Caldas, 1995, pág. 79

${ }^{33}$ EL IRIS. No. 14, Santa Marta, 1853, pág. 2.

${ }^{34}$ Ibid. 
para el baile que se iniciaría pasadas las 8 de la noche.

La música de la banda local fue espléndida, animó el baile de la noche "el cual no dejó que desear, ayudando a embellecerlo una fuente manando ricas aguas de olor, las cuales en su descenso caían en tazas de fina porcelana. La fuente estaba colgada en el punto céntrico de la sala del baile, descansando sobre una base cuadrangular y en cada uno de sus frentes se leían" ${ }^{35}$ consignas alusivas a Obando, la paz, la libertad, el progreso y otras. La prensa local no nos informa de los pormenores de los dos días siguientes, pero conociendo el espíritu festivo de los samarios, no dudamos en pensar que todo lo programado se verificó. El mismo semanario nos dice que "el programa que insertamos a continuación, dará una idea de los regocijos públicos que han tenido lugar en Santa Marta con motivo de la inauguración en $1^{\mathrm{o}}$ de abril, de la Administración del Ciudadano General José María Obando". ${ }^{36}$

Interesante destacar el hecho sociopolítico de que el gobierno local es el encargado de proclamar la fiesta, desde el 26 de marzo a través de un programa oficial que incluyó discursos, recorrido por las calles y ubicación del retrato del Presidente. El programa prevé, en las mañanas, disfraces y regocijos públicos, bebidas, toros en la Plaza de la Constitución, hoy "Parque Bolívar", bailes en las horas de la noche, mucha música y se insiste en que durante los días de regocijo debe haber en las noches "iluminación general". También vale la pena resaltar que muchos festejos tuvieron su origen en los partidos políticos y son acogidos por las autoridades samarias con entusiasmo y se asumen como oficiales e institucionales.

El hecho político-militar de haber vencido a los españoles y consolidarse la Nación conllevó a introducir en el calendario fiestas patrias, como días festivos. Al altar y al púlpito, escenarios de los sacerdotes, les aparece competidor en la medida en que los discursos cambian de escenarios, de contenidos y de autores: ahora son los políticos quienes se encargan de hacerlos. Las campanas ya no sólo señalarán la hora de la misa, sino que serán símbolos de alegría por el triunfo político o militar, las procesiones compiten en importancia con los desfiles, porque los partidarios participarán masivamente para mostrar su poder popular expresado en las masas; las imágenes de los santos encuentran competidores al introducirse en los desfiles retratos de los triunfadores en las gestas políticas; el

${ }^{35}$ Ibid.

${ }^{36}$ Ibid. ritual religioso debe competir con el patriótico que dada la pasión por la política se fortalece cada día más. 


\section{BIBLIOGRAFÍA}

BACHTIN, Michael. (1974) La cultura popular en el medioevo y en el renacimiento, Barcelona: Barral, 345p.

BURKE, Peter. (1991) La cultura popular en la Europa Moderna, Madrid: Alianza, 445 p.

DA MATTA, Roberto. (2002) Carnavales, malandros y héroes, México: Fondo de Cultura Económica, 352 p.

GONZÁLEZ PÉREZ, Marcos. (1993) El calendario festivo. En: Los Imaginarios y la cultura popular, Bogotá: Cerec, pp. 23-34.

(1995) Bajo el Palio y el Laurel, Bogotá: Universidad Distrital Francisco José de Caldas, 100 p.

REY SINNING, Edgar. (2004) El Carnaval, la segunda vida del pueblo, Bogotá: Plaza \& Janes-Universidad Simón Bolívar, 221 p.

\section{PRENSA CONSULTADA:}

GACETA MERCANTIL, No. 78, 4 de abril de 1849, Santa Marta.

EL CHURIADOR, No. 9, 15 de abril de 1849, Santa Marta, 5 p.

EL CHURIADOR, No. 5, 18 de marzo de 1849, Santa Marta, 4 p.

EL CHURIADOR, No. 6, 25 de marzo de 1849, Santa Marta, 4 p.

EL CHURIADOR, No. 7, $1^{\circ}$ de abril de 1849, Santa Marta, 4 p.

EL CÓlERA, No. 2, 20 de enero de 1850, Santa Marta, 4 p.

EL IRIS, No. 14, 7 de abril de 1853, Santa Marta, 4 p.

EL LÁTIGO, No. $1^{\circ}, 8$ de agosto de 1850, Santa Marta, 4 p.

EL LÁTIGO, No. 7, 6 de noviembre de 1850, Santa Marta, 4 p.

EL SEMANARIO DE SANTAMARTA, No. 25, 13 de abril, 1845, 4 p.

LA FRIOLERA, No. 5, 14 de abril de 1845, Santa Marta, 4 p.

LA FRIOLERA, No. 3, 22 de marzo de 1845, Santa Marta, 4 p.

LA SITUACIÓN, No. 4, 8 de marzo de 1852, Santa Marta, 4 p.

\section{BIOGRAFÍA}

\section{EDGAR REY SINNING}

Escritor, investigador de temas sobre la cultura popular del Caribe colombiano, docente universitario y conferencista. Sociólogo (Universidad Cooperativa de Colombia- Sede Bogotá) y Magíster en Educación, Filosofía Latinoamericana (Universidad Santo Tomas). Actualmente se desempeña como Director del Canal Regional Telecaribe. 